\title{
Potentiometric Performance of a Highly Flexible-Shaped Trifunctional Sensor Based on $\mathrm{ZnO} / \mathrm{V}_{2} \mathrm{O}_{5}$ Microrods
}

\author{
Alfred Bekoe Appiagyei and Jeong In Han * (D) \\ Department of Chemical and Biochemical Engineering, Dongguk University, Seoul 04620, Korea; \\ 2018126719@dgu.ac.kr \\ * Correspondence: hanji@dongguk.edu; Tel.: +82-2-2260-3364
}

check for updates

Citation: Appiagyei, A.B.; Han, J.I. Potentiometric Performance of a Highly Flexible-Shaped Trifunctional Sensor Based on $\mathrm{ZnO} / \mathrm{V}_{2} \mathrm{O}_{5}$

Microrods. Sensors 2021, 21, 2559.

https://doi.org/10.3390/s21072559

Academic Editors: Bruno Ando and Cecilia Cristea

Received: 18 February 2021

Accepted: 4 April 2021

Published: 6 April 2021

Publisher's Note: MDPI stays neutral with regard to jurisdictional claims in published maps and institutional affiliations.

Copyright: (c) 2021 by the authors. Licensee MDPI, Basel, Switzerland. This article is an open access article distributed under the terms and conditions of the Creative Commons Attribution (CC BY) license (https:// creativecommons.org/licenses/by/ $4.0 /)$.

\begin{abstract}
A trifunctional flexible sensor was fabricated on a polyethylene terephthalate (PET) fiber surface. Synthesized $\mathrm{ZnO}$ and $\mathrm{ZnO} / \mathrm{V}_{2} \mathrm{O}_{5}$ composite were coated on $\mathrm{ZnO}$ seed layer sputtered PET fiber. X-ray diffraction (XRD) and photoelectron spectroscopy (XPS) techniques confirmed the exact formation of $\mathrm{ZnO}$ and $\mathrm{ZnO} / \mathrm{V}_{2} \mathrm{O}_{5}$. The fabricated $\mathrm{ZnO} / \mathrm{V}_{2} \mathrm{O}_{5}$ on $\mathrm{ZnO}$ seeds base temperature sensor recorded better electrical properties and reversibility with a maximum temperature coefficient resistance (TCR) of $0.0111^{\circ} \mathrm{C}^{-1}$. A calibration curve $(\mathrm{R}=0.9941)$ within glucose concentration of $(10 \mu \mathrm{M}-10 \mathrm{mM})$ was obtained at $+0.8 \mathrm{~V}$ vs. $\mathrm{Ag} / \mathrm{AgCl}$ from current-voltage curves which assisted in calculating glucose sensitivity, limit of detection (LOD), limit of quantification (LOQ). The electrode achieved an outstanding performance of sensitivity $\left(72.06 \mu \mathrm{AmM}^{-1} \mathrm{~cm}^{-2}\right)$, LOD $(174 \mu \mathrm{M})$, and LOQ $(582 \mu \mathrm{M})$ at optimum deposition time. Interference from oxidation of interfering biomolecules such as ascorbic acid, dopamine, and uric acid were negligible compared to glucose. Finally, the fabricated electrode was employed as a $\mathrm{pH}$ sensor and displayed a $\mathrm{pH}$ sensitivity of $42.26 \mathrm{mV} / \mathrm{pH}(\mathrm{R}=0.9922)$. This fabricated $\mathrm{ZnO} / \mathrm{V}_{2} \mathrm{O}_{5}$ electrode exhibited high sensitivity and a stable combined temperature, glucose, and $\mathrm{pH}$ sensor which is promising for development of multifunctional sensors in next generation wearables.
\end{abstract}

Keywords: flexible sensor; PET fiber; simultaneous hydrothermal; multifunctional detectors; bending; wearables

\section{Introduction}

Recently, wearable devices have been developed and commercialized due to their broad potential and application [1]. They represent the electronic devices that are applied to the human body and skin to monitor how the body is functioning to give the user understanding of themselves [2,3]. Sensor devices represent one of the most influential parts of wearable device technology which has progressively gained attention from both academic and industrial applications $[4,5]$. Numerous types of sensors including humidity sensors [6], temperature sensors [7], pressure sensors [8], bio-sensors [9], strain sensors [10], $\mathrm{pH}$ sensors [11], etc., are researched for wearable application.

Traditionally, electronic devices were fabricated on planar substrates such as glass and metal substrates [12]. These rigid substrate based devices deliver high performances but are not applicable as wearables because of their inflexible nature which is a major drawback [13]. The application of these various sensors to the human body requires flexible substrates with high compatibility to the human body or other surfaces [3]. To overcome the poor flexibility and stretchability of these conventional substrates, flexible substrates such as polyethylene terephthalate (PET) and polydimethylsiloxane (PDMS) have been investigated rather, to substitute rigid and expensive glass and metal substrates $[14,15]$. Besides planar type substrates, cylindrical fiber type substrates with excellent flexibility have also been developed. Recently, our research group developed a flexible cylindrical fiber shaped temperature sensor based graphene/Ni layer which showed a positive temperature coefficient resistance (TCR) of $0.018{ }^{\circ} \mathrm{C}^{-1}$ [16]. Unlike the woven type which has a bundle 
of fibers, the PET fiber employed in our research group is the monofilament type. The woven type consists of a cluster of fibers fabricated together by weaving, knitting, braiding, etc., which involves high manufacturing costs. Our previously reported works have proved the flexibility and compatibility of the PET fiber as a sensor substrate [17]. In this work, similar flexible PET fiber is employed as a substrate for a multifunctional sensor purpose. A trifunctional sensor that features temperature, glucose, and $\mathrm{pH}$ sensing on a PET fiber is designed. Combined precise measurement and self-monitoring of these variables are very critical in the body especially in medicine that necessitates a multifunctional sensor preferably to the individual single sensors $[18,19]$. They can practically be tested through either direct body contact or using biofluids such as sweat and saliva.

Zinc oxide $(\mathrm{ZnO})$ is the most common oxide material which has continuously been researched due to its several properties suitable for sensor device. $\mathrm{ZnO}$ possesses high exciton binding energy $(60 \mathrm{meV})$, high band gap energy $(3.37 \mathrm{eV})$, and a high surface area to volume ratio structure [20]. Liao and coworkers reported $\mathrm{ZnO}$ based multifunctional nanosensor which detects strain, temperature, and ultraviolet (UV) on polyurethane (PU) fiber, however, the surface state was very rough [21]. Hasan et al. used direct current (DC) magnetron sputtering for depositing $\mathrm{ZnO}$ thin film and applied for temperature sensor [22]. Marie et al. also introduced $\mathrm{ZnO}$ nanorods-based glucose sensor on indium tin oxide (ITO) substrate which achieved sensitivity of $10.911 \mathrm{~mA} / \mathrm{mMcm}^{2}$ and a lower limit of detection of $0.22 \mu \mathrm{M}$ [23].

Oxides of vanadium exist as $\mathrm{VO}, \mathrm{VO}_{2}, \mathrm{~V}_{2} \mathrm{O}_{3}$, and $\mathrm{V}_{2} \mathrm{O}_{5}$ depending on the oxidation state. Vanadium $(\mathrm{V})$ oxide $\left(\mathrm{V}_{2} \mathrm{O}_{5}\right)$ is known as an active material for gas sensor, UV detection, catalyst, solar cell, and other electrochromic applications due to its wide optical bandgap, outstanding thermoelectric properties, and good physiochemical thermal stability [24-26]. We anticipate a combined $\mathrm{ZnO}$ and $\mathrm{V}_{2} \mathrm{O}_{5}$ structure can provide enhanced direct electron transfer through biochemical interfering reactions. Various synthetic methods have been used to prepare $\mathrm{ZnO}$ structures (rods, tubes, wires, and sheets) particularly for sensor application which include hydrothermal, solvothermal, microemulsion, and sol gel for sensor application [27]. Notably, hydrothermal is the most beneficial technique as it is simple and mainly focusing on the surface modification with controlled structural morphology. The hydrothermal deposition of $\mathrm{V}_{2} \mathrm{O}_{5}$ on $\mathrm{ZnO}$ rods may exhibit good electrical properties due to their large optical band gap, stability, layered morphology, and multivalent behaviors [28]. These properties are crucial for a wide range of medical and industrial applications such as energy storage devices, electrochromic devices, solar cells, photochromic devices, and microbolometers, etc. [29,30].

Binachi group focused on $\mathrm{V}_{2} \mathrm{O}_{5}$ based thin film as a transparent temperature and gas sensor with room temperature chemoresistive properties [31]. Xue et al. reported the piezotronic effect of $\mathrm{ZnO}$ based temperature sensors. Recently, Mani et al. also focused on $\mathrm{ZnO}$ based microfluidic $\mathrm{pH}$ sensors for circulating tumor cells in blood [32]. Based on the above, the $\mathrm{ZnO} / \mathrm{V}_{2} \mathrm{O}_{5}$ composite may be suitable for multifunctional sensor applications. Though Rahman et al. reported on a d-glucose sensor based on $\mathrm{ZnO} / \mathrm{V}_{2} \mathrm{O}_{5}$ which showed sensitivity of $1.27 \times 10^{-3} \mu \mathrm{A \mu M}^{-1} \mathrm{~cm}^{-2}$ with $125.25 \mathrm{mM}$ limit of detection. This active material has the potential to be applied to multiple sensor applications [33]. Based on our knowledge, there is no report on $\mathrm{ZnO} / \mathrm{V}_{2} \mathrm{O}_{5}$ based multifunctional sensors on a flexible substrate for temperature, glucose and $\mathrm{pH}$ combined detections. Upon various ways of seed layer coating, radio frequency (RF) magnetron sputtering was applied in this work for $\mathrm{ZnO}$ deposition. A rotating device our research group uniquely designed was utilized. During the deposition process, PET fiber was continuously rotated which led to an even and uniform surface condition. This work presents newly designed $\mathrm{ZnO} / \mathrm{V}_{2} \mathrm{O}_{5}$-based sensor coated on cylindrical PET fiber for detecting the variables stated above. This type of multifunctional detectors are important for developing industrial and biomedical applications. 


\section{Materials and Methods}

\subsection{Materials}

Analytical grades of zinc nitrate hexahydrate $\left(\mathrm{Zn}\left(\mathrm{NO}_{3}\right)_{2} \cdot 6 \mathrm{H}_{2} \mathrm{O}, \mathrm{CAS}\right.$ number: 1019618-6), hexamethylenetetramine $\left(\mathrm{C}_{6} \mathrm{H}_{12} \mathrm{~N}_{4}\right.$, CAS number: 100-97-0), ammonium metavanadate $\left(\mathrm{NH}_{4} \mathrm{VO}_{3}, \mathrm{CAS}\right.$ number: 7803-55-6), oxalic acid dihydrate $\left(\mathrm{H}_{2} \mathrm{C}_{2} \mathrm{O}_{4} \cdot 2 \mathrm{H}_{2} \mathrm{O}\right.$, CAS number: 6153-56-6), polyvinylidene fluoride (PVDF, CAS number: 24937-79-9), carbon black (CAS number: 1333-86-4), nafion (CAS number: 31175-20-9) and glucose oxidase (GOx, CAS number: 9001-37-0) from aspergillus niger were used. Acetone, methanol, sodium hydroxide (NaOH, CAS number: 1310-73-2), hydrochloric acid ( $\mathrm{HCl}, \mathrm{CAS}$ number: 764701-0), and phosphate buffered saline (PBS, CAS number: 7647-14-5) were used as solvents. PET fiber (CAS number: 25038-59-9) was also used as substrate. All chemicals, solvents, and substrate were purchased from Sigma Aldrich and used without further purification.

\subsection{Fabrication of $\mathrm{ZnO} / \mathrm{V}_{2} \mathrm{O}_{5}$ on $\mathrm{ZnO}$ Sputtered PET Fiber}

\subsubsection{ZnO Seed Deposition}

A bare PET fiber with thickness $300 \mu \mathrm{m}$ and length $7 \mathrm{~cm}$ was employed as a flexible substrate. PET fiber was firstly cut and straightened on a hot plate for $30 \mathrm{~min}$ at $100{ }^{\circ} \mathrm{C}$. After forming a straightened PET fiber, it was sequentially sonicated in methanol and acetone for $10 \mathrm{~min}$ each. The PET fiber was then finally rinsed with deionized water and dried in an oven at $65{ }^{\circ} \mathrm{C}$ for $30 \mathrm{~min}$. The first step was $\mathrm{ZnO}$ seed layer coating by RF magnetron sputtering. A rotating device which our research group firstly developed was used during the sputtering procedure. PET fiber was rotated at constant speed of $0.5 \mathrm{rev} / \mathrm{s}$ inside the sputter chamber with sputtering conditions; working power of $100 \mathrm{~W}$; working pressure of $3.15 \times 10^{-2}$ torr; Ar and $\mathrm{O}_{2}$ flow rates of 45 SCCM and 15 SCCM respectively. Various deposition times (10 $\mathrm{min}, 20 \mathrm{~min}$, and $30 \mathrm{~min}$ ) were applied to study the effect of seed layer thickness on characteristics of $\mathrm{ZnO}$.

\subsubsection{Simultaneous Hydrothermal Growth of $\mathrm{ZnO}$ and $\mathrm{ZnO} / \mathrm{V}_{2} \mathrm{O}_{5}$}

The typical hydrothermal growth of $\mathrm{ZnO}$ and $\mathrm{ZnO} / \mathrm{V}_{2} \mathrm{O}_{5}$ on the seed layer: $0.1 \mathrm{M}$ equimolar concentration of $\mathrm{Zn}\left(\mathrm{NO}_{3}\right)_{2} \cdot 6 \mathrm{H}_{2} \mathrm{O}$ and $\mathrm{C}_{6} \mathrm{H}_{12} \mathrm{~N}_{4}$ were used as precursors. The precursors were mixed together in $70 \mathrm{~mL}$ of water and stirred for $24 \mathrm{~h}$. After stirring, the solution was transferred into a Teflon-lined autoclave. The ZnO seed layer on PET fiber was placed in the autoclave and maintained at $95^{\circ} \mathrm{C}$ for $8 \mathrm{~h}$. After cooling, part of the obtained samples was washed three times with water and ethanol and finally dried to obtain $\mathrm{ZnO}$ microrods. $1.2 \mathrm{~g}$ of $\mathrm{NH}_{4} \mathrm{VO}_{3}$ and $0.5 \mathrm{~g}$ of $\mathrm{H}_{2} \mathrm{C}_{2} \mathrm{O}_{4} \cdot 2 \mathrm{H}_{2} \mathrm{O}$ were dissolved in $20 \mathrm{~mL}$ of water and stirred for $6 \mathrm{~h}$. The blue color solution obtained was transferred to the above autoclave with part of the solution after first hydrothermal. A PET fiber was placed into the autoclave and kept at the same reaction conditions. After cooling, the resultant solution was washed three times with water and ethanol and finally dried to obtain $\mathrm{ZnO} / \mathrm{V}_{2} \mathrm{O}_{5}$ composite.

\subsection{Material Characterization}

The formation of synthesized $\mathrm{ZnO}$ and $\mathrm{ZnO} / \mathrm{V}_{2} \mathrm{O}_{5}$ particles was confirmed using $X$-ray diffractometer (Rigaku Ultima IV) with $\mathrm{Cu} \mathrm{k} \alpha$ radiations $(\lambda=1.5046 \AA$ ) over theta range from $20^{\circ}$ to $80^{\circ}$. Further characterizations including field emission scanning electron microscopy (FESEM, JSM-7500F) was used to study the morphology of the prepared powder. FESEM image of PET fiber coated with $\mathrm{ZnO}$ was also recorded. The elemental composition was confirmed using energy dispersive X-ray spectroscopy (EDX) and X-ray photoelectron spectroscopy (XPS, Thermo Scientific K-Alpha).

\subsection{Construction and TCR Measurement of Temperature Sensor on PET Fiber}

After the growth of $\mathrm{ZnO} / \mathrm{V}_{2} \mathrm{O}_{5}$ composite on PET fiber, the assembled device was placed on a sliding glass. Copper tape was attached to achieve better contact for I-V measurement using Keithley electrometer (Model 6517). The resistance of the composite was measured for five different points $\left(25^{\circ} \mathrm{C}, 40^{\circ} \mathrm{C}, 60^{\circ} \mathrm{C}, 80^{\circ} \mathrm{C}\right.$, and $\left.100{ }^{\circ} \mathrm{C}\right)$ in a voltage 
range from $-5 \mathrm{~V}$ to $5 \mathrm{~V}$. Based on the resistance from the I-V curves, TCR was calculated which was utilized as the temperature sensing parameter. To study the reversibility of $\mathrm{ZnO}$ and $\mathrm{ZnO} / \mathrm{V}_{2} \mathrm{O}_{5}$ temperature sensor, after increasing the temperature to $100{ }^{\circ} \mathrm{C}$, the temperature was maintained for $1 \mathrm{~h}$ and the resistance was measured at similar temperature points during cooling.

\subsection{Construction of Electrochemical Sensor on PET Fiber}

All the electrochemical measurements were carried out using Biologic (SP-150) Potentiostat. The $\mathrm{ZnO}-\mathrm{V}_{2} \mathrm{O}_{5}$ coated PET fiber was used as a working electrode, $\mathrm{Ag} / \mathrm{AgCl}$ electrode in $0.2 \mathrm{M} \mathrm{KCl}$ as a reference electrode, and a Pt wire electrode as a counter electrode with different concentrations of $\mathrm{NaOH}$ and $\mathrm{HCl}$ as electrolytes. Prior to the electrochemical test, an electrode was prepared by thoroughly mixing active material $\left(\mathrm{ZnO} / \mathrm{V}_{2} \mathrm{O}_{5}\right)$, carbon black, and PVDF in a mass ratio of 80:10:10. The prepared sample was coated on the $\mathrm{ZnO}$ seed layered PET fiber using a dip coater. The fabricated electrode was dried in a vacuum oven at $60^{\circ} \mathrm{C}$ and finally used as an electrochemical sensor.

\subsubsection{Enzymatic Glucose Sensing Analysis}

To fabricate the glucose sensor, glucose oxidase (GOx) was coated on $\mathrm{ZnO}$ microrods and $\mathrm{ZnO} / \mathrm{V}_{2} \mathrm{O}_{5}$ composite using dip-coating method with a dip-coating speed of $0.5 \mathrm{~mm} / \mathrm{s}$. Different concentrations of glucose were mixed with the $17 \mathrm{mM}$ PBS solution solvent employed as the electrolyte. After GOx coating, the array was dried out overnight followed by nafion (5\%) coating. Nafion was also coated by dip-coating method with similar dipcoating speed and dried overnight. The prepared electrode was applied as a working electrode for glucose sensing. The current was measured using the electrochemical system with $\mathrm{ZnO}-\mathrm{V}_{2} \mathrm{O}_{5}$ coated PET fiber as the working electrode.

\subsection{2. $\mathrm{pH}$ Sensing Analysis}

The $\mathrm{ZnO} / \mathrm{V}_{2} \mathrm{O}_{5}$ composite array was also applied in $\mathrm{pH}$ sensing for $\mathrm{pH}$ levels between 1 and 12 using a potentiometric technique recording the potential difference across the $\mathrm{Ag} / \mathrm{AgCl}$ reference electrode and $\mathrm{ZnO} / \mathrm{V}_{2} \mathrm{O}_{5}$ working electrode. The $\mathrm{pH}$ was controlled by using a mixture of $\mathrm{NaOH}$ and $\mathrm{HCl}$ solvents in different compositions as the electrolyte.

\section{Results and Discussion}

\subsection{Materials}

Scheme 1 illustrates the schematic representation of the fabrication of $\mathrm{ZnO} / \mathrm{V}_{2} \mathrm{O}_{5}$ composite on a single PET fiber. ZnO seed layer was firstly deposited on cleaned cylindrical PET fiber by RF magnetron sputtering at different deposition times (10 $\mathrm{min}, 20 \mathrm{~min}$, and $30 \mathrm{~min}$ ) using a rotating device (Figure S1a) designed by our research group in order to ensure a uniform thin film deposition. It is apparent that PET fiber has a cylindrical feature and fine surface condition. (Figures $\mathrm{S} 1 \mathrm{~b}$ and $\mathrm{S} 2$ ) The rotation speed of the device was maintained at $0.5 \mathrm{rev} / \mathrm{s}[17,34]$. The $\mathrm{ZnO} / \mathrm{V}_{2} \mathrm{O}_{5}$ was grown on the $\mathrm{ZnO}$ seed layer using a two-step hydrothermal process. A feasible mechanism for the growth of $\mathrm{ZnO} / \mathrm{V}_{2} \mathrm{O}_{5}$ microrods is as follows (Equations (1)-(5)):

$$
\begin{gathered}
\mathrm{Zn}\left(\mathrm{NO}_{3}\right)_{2} \cdot 6 \mathrm{H}_{2} \mathrm{O} \rightarrow \mathrm{Zn}(\mathrm{OH})_{2(\mathrm{aq})}+5 \mathrm{H}_{2} \mathrm{O}+2 \mathrm{NO}_{3(\mathrm{aq})}^{-} \\
\mathrm{Zn}(\mathrm{OH})_{2(\mathrm{aq})} \rightarrow \mathrm{ZnO}_{(\mathrm{s})}+6 \mathrm{H}_{2} \mathrm{O} \\
2 \mathrm{NH}_{4} \mathrm{VO}_{3}+\mathrm{H}_{2} \mathrm{C}_{2} \mathrm{O}_{4} \cdot 6 \mathrm{H}_{2} \mathrm{O} \rightarrow \mathrm{V}(\mathrm{OH})_{4(\mathrm{aq})}+\left(\mathrm{NH}_{4}\right)_{2} \mathrm{C}_{2} \mathrm{O}_{4(\mathrm{~s})}+\mathrm{H}_{2(\mathrm{~g})} \\
2 \mathrm{~V}(\mathrm{OH})_{4(\mathrm{aq})} \rightarrow \mathrm{V}_{2} \mathrm{O}_{5}+3 \mathrm{H}_{2} \mathrm{O}+\mathrm{H}_{2(\mathrm{~g})} \\
\mathrm{ZnO}+\mathrm{V}_{2} \mathrm{O}_{5} \rightarrow \mathrm{ZnO} \cdot \mathrm{V}_{2} \mathrm{O}_{5}
\end{gathered}
$$


(b) ZnO seed layer on PET

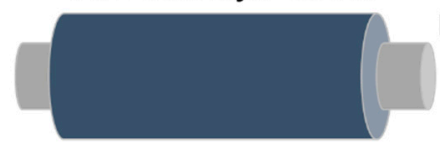

Hydrothermal
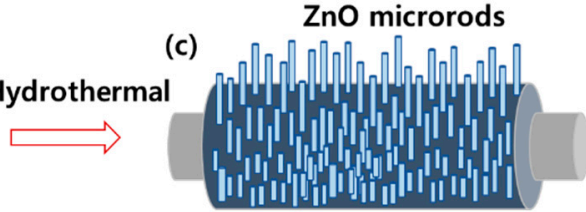

RF Sputtering

(a)
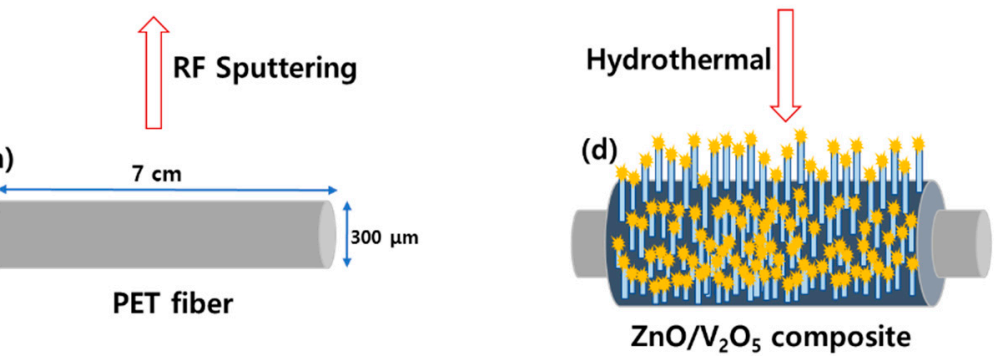

Scheme 1. Representation of the fabrication of $\mathrm{ZnO}$ microrods and $\mathrm{ZnO} / \mathrm{V}_{2} \mathrm{O}_{5}$ composite on a PET fiber. (a) bare PET monofilament substrate (b) RF sputtered $\mathrm{ZnO}$ seeds on PET fiber. Hydrothermal synthesis of (c) $\mathrm{ZnO}$ microrods and (d) $\mathrm{ZnO} / \mathrm{V}_{2} \mathrm{O}_{5}$ composite on PET fiber.

The development of $\mathrm{ZnO} / \mathrm{V}_{2} \mathrm{O}_{5}$ composite was accomplished primarily by heterogeneous nucleation of particles in the solution, followed by re-aggregation of the particles to yield rod-like structures according to the Ostwald principle. The microrods re-aggregate with each other and with $\mathrm{V}_{2} \mathrm{O}_{5}$ particles through Van Der Waals interaction and finally form the $\mathrm{ZnO} / \mathrm{V}_{2} \mathrm{O}_{5}$ microrods.

The flexibility of the coated fiber is confirmed by bending it as shown in Figure 1. A PET fiber of length $\left(\mathrm{L}_{\mathrm{o}}\right), 7.0 \mathrm{~cm}$ was bent at a radius of $18.5 \mathrm{~mm}$. The change in length $(\Delta \mathrm{L})$ recorded was $2.9 \mathrm{~cm}$ and showed an applied strain of $41.4 \%$.

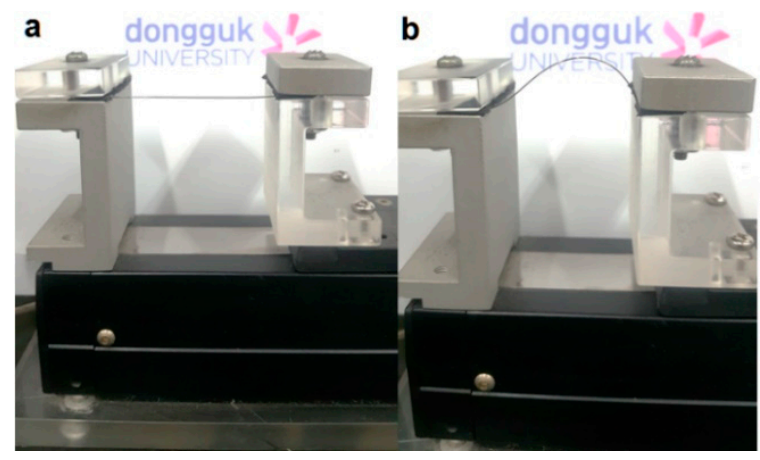

Figure 1. Photographic image of $\mathrm{ZnO} / \mathrm{V}_{2} \mathrm{O}_{5}$ deposited PET single fiber (a) at straight and (b) fullbending conditions.

The surface morphology and the grain size of the samples were observed using FESEM. The FESEM images (Figure 2a1-c1) depict increase in grain size with corresponding reduction in the grain boundary as deposition time increases. The thicknesses of $\mathrm{ZnO}$ seeds are approximately $330 \mu \mathrm{m}$ for $10 \mathrm{~min}$ deposition, $360 \mu \mathrm{m}$ for $20 \mathrm{~min}$ deposition and $640 \mu \mathrm{m}$ for $30 \mathrm{~min}$ deposition, respectively [35]. Hydrothermally synthesized $\mathrm{ZnO}$ well-oriented growth was also studied from the FESEM characterization (Figure 2a2-c2). It exhibited uniform microrods-like structure and an increased thickness of the rods with increase in deposition time which is due to the grain boundary influences [36]. The actual morphology of $\mathrm{ZnO}$ microrods is hexagonal which clearly appears in the image. They are dense and crystalline. The surface grains are composed of regularly shaped grains in a bundle of columnar and triangular shapes. Comparatively, the surface grain size is larger for higher deposition times. Figure 2a3-c3 depicts the surface morphology of $\mathrm{ZnO} / \mathrm{V}_{2} \mathrm{O}_{5}$ composite grown on the seed layer. The particles are agglomerated and dense and show different morphology from the pristine $\mathrm{ZnO}$. The microrod morphology of the $\mathrm{ZnO} / \mathrm{V}_{2} \mathrm{O}_{5}$ 
formed influences their intrinsic sensing abilities. The formed microrod structure provides conductive pathways for the electrons, which helps to achieve good electrical characteristics. Figure $\mathrm{S} 3$ represents a cross-section of the $\mathrm{ZnO} / \mathrm{V}_{2} \mathrm{O}_{5}$ composite on $\mathrm{ZnO}$ seeds showing the thickness of the layers. This reveals the rod structure of $\mathrm{ZnO} / \mathrm{V}_{2} \mathrm{O}_{5}$ layers. $\mathrm{ZnO}$ microrods exhibit a thickness of about $1.02 \mu \mathrm{m}$ and $\mathrm{ZnO} / \mathrm{V}_{2} \mathrm{O}_{5}$ exhibits a layer thickness of $2.31 \mu \mathrm{m}$ for all the three samples. Represented in Figure S4, coupled EDX spectroscopy was carried out to analyze the elemental composition of the synthesized composite. It depicts the presence of all the expected elements $(\mathrm{Zn}, \mathrm{V}, \mathrm{O})$ with elemental composition $(\mathrm{Zn}-28.61 \%$, $\mathrm{V}-15.04 \%$, and $\mathrm{O}-56.34 \%$ )

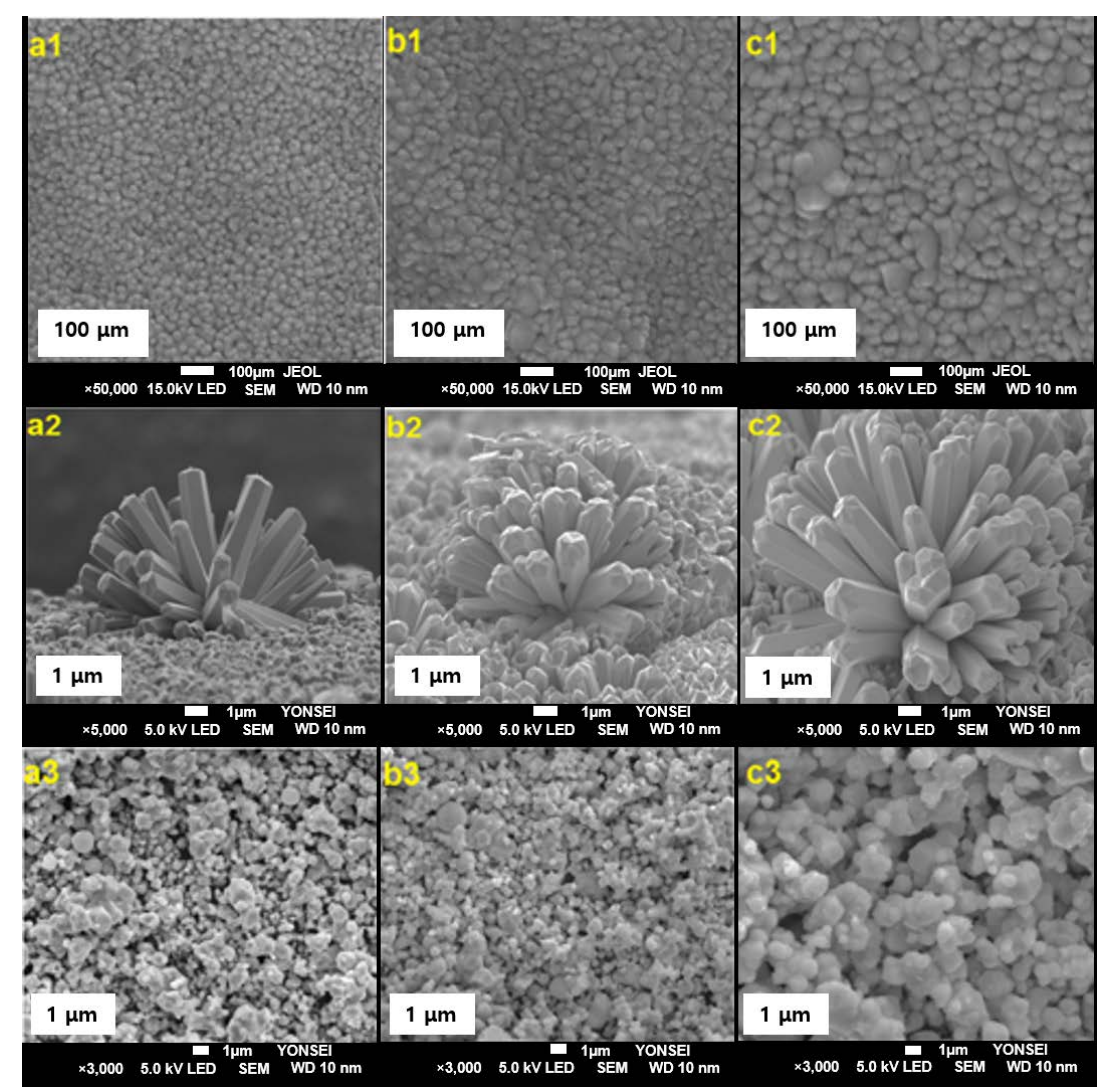

Figure 2. FESEM images of $\mathrm{ZnO}$ seed layer (a1,b1,c1); $\mathrm{ZnO}$ microrods $(\mathbf{a} 2, \mathbf{b} 2, \mathbf{c} 2)$ and $\mathrm{ZnO} / \mathrm{V}_{2} \mathrm{O}_{5}$ composite $(\mathbf{a} 3, \mathbf{b} 3, \mathbf{c} 3)$ for deposition time of $10 \mathrm{~min}, 20 \mathrm{~min}$, and $30 \mathrm{~min}$ respectively.

Hydrothermally synthesized samples $\left(\mathrm{ZnO}\right.$ and $\left.\mathrm{ZnO} / \mathrm{V}_{2} \mathrm{O}_{5}\right)$ experienced extremely oriented growth which were further studied by XRD and XPS techniques. The XRD studies were plotted in Figure 55 and Figure 3 for $\mathrm{ZnO}$ and $\mathrm{ZnO} / \mathrm{V}_{2} \mathrm{O}_{5}$, respectively. The expected peaks distinctly appeared which indicate the formation of $\mathrm{ZnO}$ microrods for all samples with different deposition times. They showed similar $2 \theta$ values of $31.72^{\circ}, 34.38^{\circ}, 36.2^{\circ}$, $47.54^{\circ}, 56.62^{\circ}$ and $62.78^{\circ}$ independent of the deposition times as represented in Figure S5. Moreover, the crystallinity and orientation of synthesized $\mathrm{ZnO}$ microrods were studied by the intensity of $\mathrm{ZnO}$ peaks. The peak heights are slightly attenuated for the $10 \mathrm{~min}$ $\mathrm{ZnO}$ deposition sample signifying lower crystallinity. These peaks indexed the hexagonal phase of the crystalline structure match with the JCPDS card: (36-1451) [28]. No extra peaks confirm a well-crystalline and pure phase $\mathrm{ZnO}$ structure. The sharp diffraction peaks in all samples (Figure $3 \mathrm{a}-\mathrm{c}$ ) at the different seed layer sputtering time on PET films authorized the polycrystalline appearance of nanoparticles. The $\mathrm{V}_{2} \mathrm{O}_{5}$ indexed orthorhombic crystalline phase matches with JCPDS: (89-0612) [37]. The other crystalline peaks correspond to the $\mathrm{ZnO}$ microrods projecting to increase the crystallinity from sharp peaks. These obtained results indicate that the growth of $\mathrm{ZnO}$ microrods are highly oriented to the $z$-axis and vertically aligned. The crystallinity data are consistent with the FESEM characterization 
results. Also, the intensity of the (002) peak was highest when the deposition time was $20 \mathrm{~min}$. Therefore, $\mathrm{ZnO} / \mathrm{V}_{2} \mathrm{O}_{5}$ with $20 \mathrm{~min}$ deposition of the seed layer had the best orientation and crystallinity.

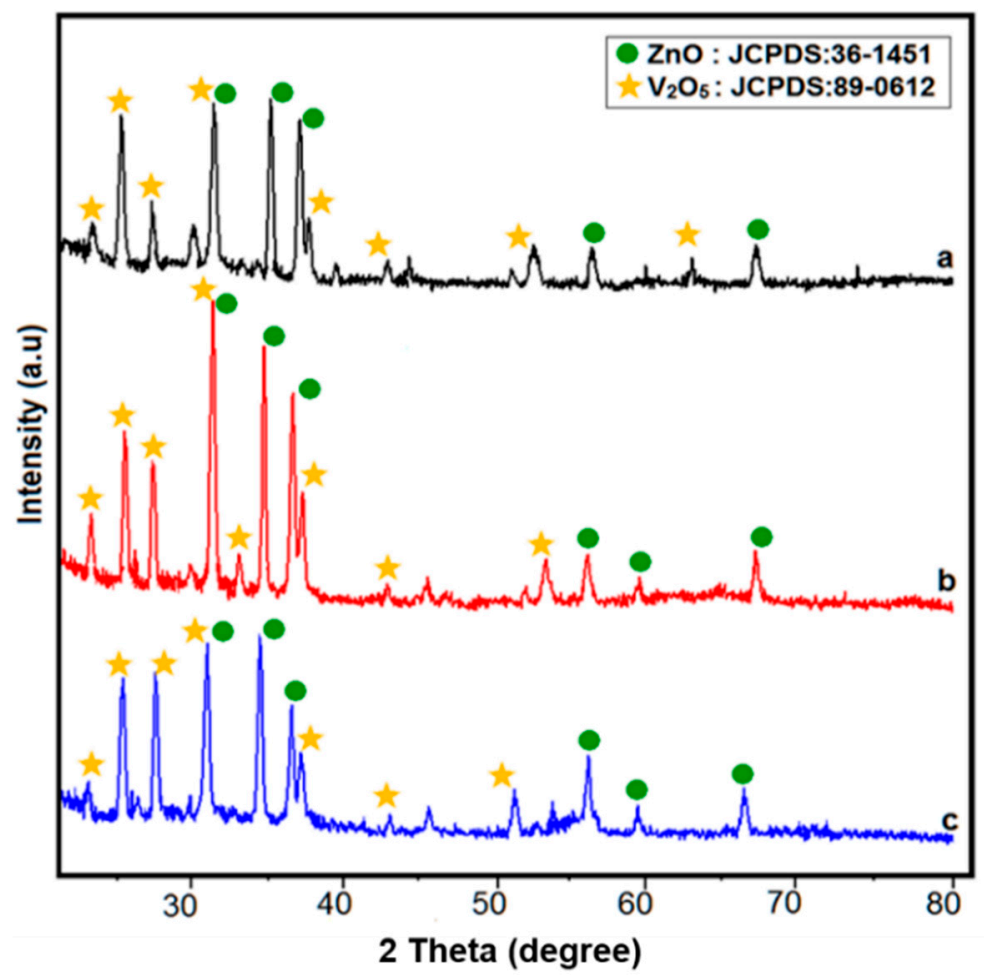

Figure 3. XRD patterns of $\mathrm{ZnO} / \mathrm{V}_{2} \mathrm{O}_{5}$ with seed layer deposition time of (a) $10 \mathrm{~min}$, (b) $20 \mathrm{~min}$, and (c) $30 \mathrm{~min}$.

Furthermore, the presence and valence state of the elements in $\mathrm{ZnO} / \mathrm{V}_{2} \mathrm{O}_{5}$ were examined with XPS studies (Figure 4). The three overall survey spectra of $\mathrm{ZnO} / \mathrm{V}_{2} \mathrm{O}_{5}$ for 10, 20, 30 min deposition times are represented in Figure $4 a-c$. These XPS graphs indicate typical $\mathrm{Zn}$ doublet peaks located around $1022 \mathrm{eV}$ and $1046 \mathrm{eV}$ and correspond to $\mathrm{Zn} 2 \mathrm{p}_{3 / 2}$ and $\mathrm{Zn} 2 \mathrm{p}_{1 / 2}$. This binding energy difference may be evidence for the $\mathrm{Zn}^{2+}$ oxidation state. The $\mathrm{O} 1 \mathrm{~s}$ reveals a prominent peak at $531 \mathrm{eV}$, which agrees with the $\mathrm{Zn}$ surrounded by the nearest oxygen to form a pure $\mathrm{ZnO} / \mathrm{V}_{2} \mathrm{O}_{5}$ composite [38]. The typical peaks around $515 \mathrm{eV}$ and $518 \mathrm{eV}$ binding energy were assigned to $\mathrm{V} 2 \mathrm{p}_{3 / 2}$ and $\mathrm{V} 2 \mathrm{p}_{1 / 2}$ of $\mathrm{V}_{2} \mathrm{O}_{5}$ [39], respectively, which are confirming the successful formation of $\mathrm{ZnO} / \mathrm{V}_{2} \mathrm{O}_{5}$ via simultaneous hydrothermal deposition.

\subsection{Temperature Sensor}

After the successful synthesis of $\mathrm{ZnO} / \mathrm{V}_{2} \mathrm{O}_{5}$ composite on $\mathrm{ZnO}$ seed layer, electrical properties were measured for temperature sensing. Figure 5 a depicts the current-voltage (I-V) curves within the applied voltage range from $-5 \mathrm{~V}$ to $5 \mathrm{~V}$ at different temperature conditions. The reciprocal of the slope indicates the electrical resistance of the electrode. Resistance values of different temperatures were applied for calculating temperature coefficient of resistance (TCR). TCR defined in Equation (6) indicates the temperature sensitivity of a certain material as a function of resistance,

$$
\mathrm{TCR}=\frac{\mathrm{R}_{2}-\mathrm{R}_{1}}{\mathrm{R}_{1}\left(\mathrm{~T}_{2}-\mathrm{T}_{1}\right)}
$$

where $R_{1}$ is initial resistance, $R_{2}$ is final resistance, $T_{1}$ is the initial temperature and $T_{2}$ is final temperature. In this work, initial temperature is $25^{\circ} \mathrm{C}$ and final temperature is $100^{\circ} \mathrm{C}$. Thus, TCR was calculated by measuring the resistance change between $25^{\circ} \mathrm{C}$ and $100{ }^{\circ} \mathrm{C}$ [16]. 


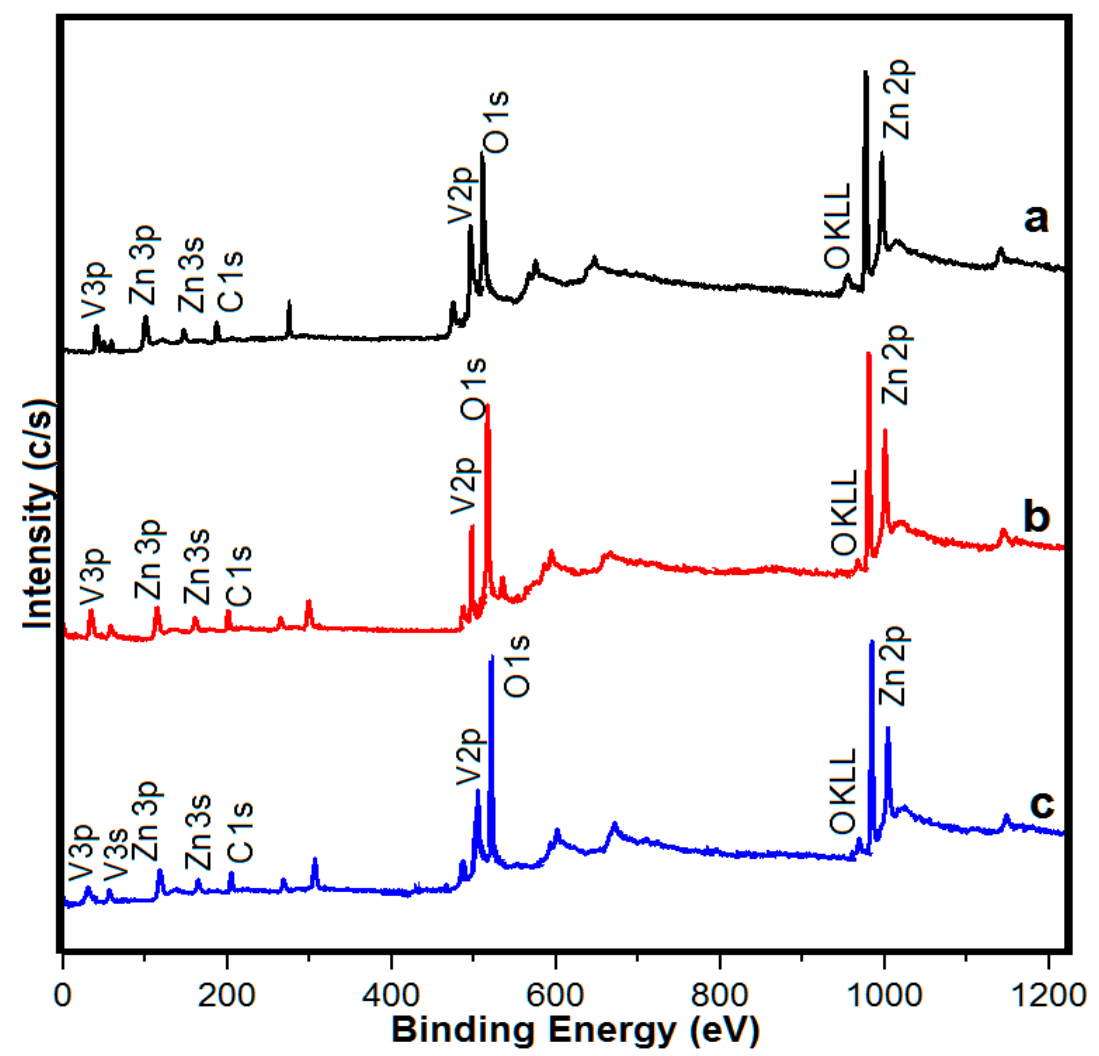

Figure 4. XPS spectra of $\mathrm{ZnO} / \mathrm{V}_{2} \mathrm{O}_{5}$ with seed layer deposition time of (a) $10 \mathrm{~min}$, (b) $20 \mathrm{~min}$, and (c) $30 \mathrm{~min}$.
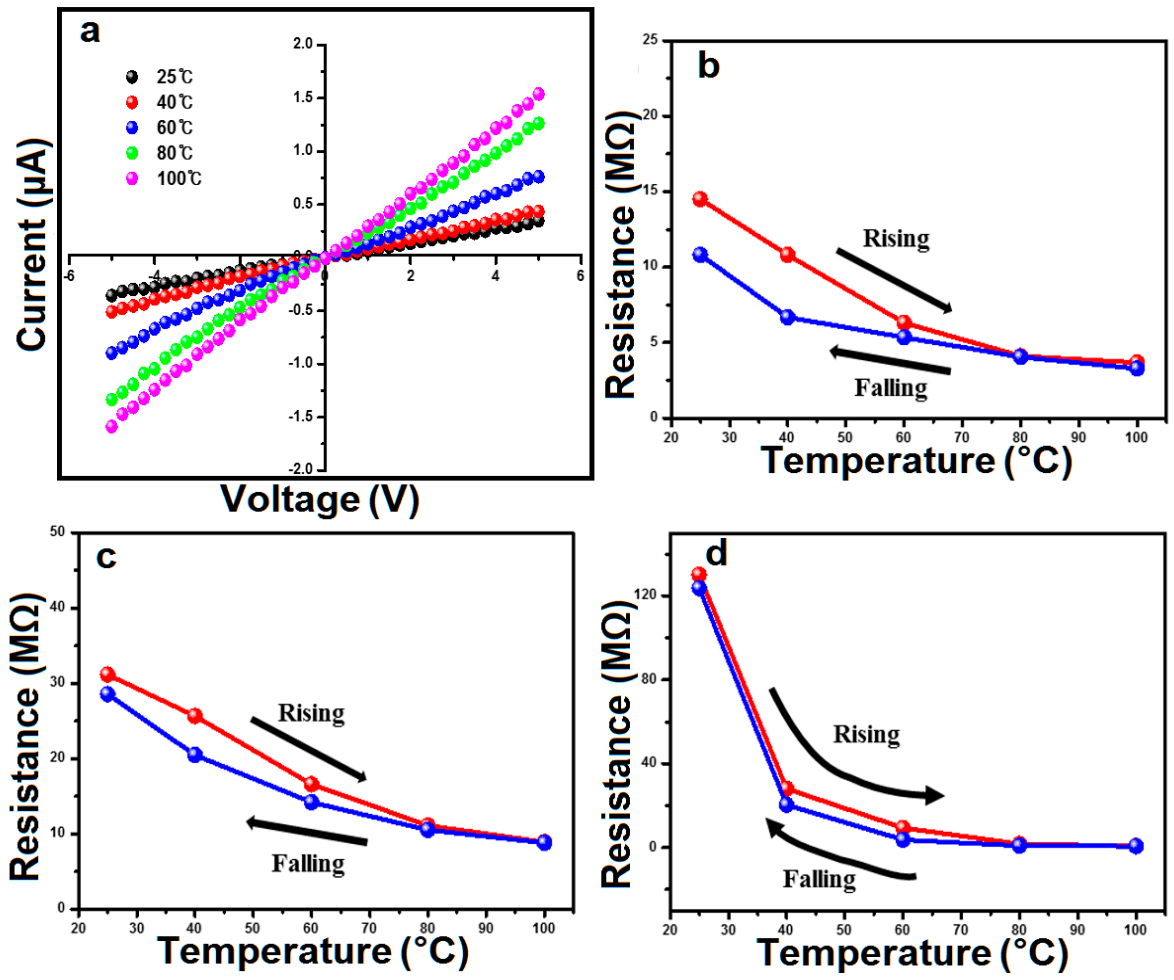

Figure 5. (a) Variation of the electrical properties of $\mathrm{ZnO} / \mathrm{V}_{2} \mathrm{O}_{5}$ temperature sensor at different temperature conditions. Resistance-temperature relation of $\mathrm{ZnO} / \mathrm{V}_{2} \mathrm{O}_{5}$ temperature sensor for seed layer deposition time of (b) $10 \mathrm{~min}$, (c) $20 \mathrm{~min}$, and (d) $30 \mathrm{~min}$. 
The change in resistance corresponding to temperature change is plotted in Figure $5 \mathrm{~b}-\mathrm{d}$. This observation represents the resistive behavior of the deposited composite on PET fiber. Resistance was measured during the cooling process to understand the reversibility of the temperature sensor. We observed an inverse relationship between resistance and temperature for the cooling similar to the heating process. All three samples showed identical behavior. The final resistance was smaller than the initial resistance, which renders a negative TCR value. This phenomenon is one of the natural behaviors of semiconductor materials. The inverse resistance-temperature relationship is because a rise in thermal energy excites electrons to move from the valence band to conduction band. More electrons jumping leads to higher current and lower resistance [37].

Reversely, the metal heating process may increase the number of vibrating atoms. Random collision of these atoms hinders the passage of electrons which explains the increase in resistance with temperature rise. For 10 min deposition sample, the resistance decreased from $14.49 \mathrm{M} \Omega$ to $3.68 \mathrm{M} \Omega$ as temperature increased from $25{ }^{\circ} \mathrm{C}$ to $100{ }^{\circ} \mathrm{C}$ (Figure $5 b$ ). In the reversible process, resistance increased from $3.27 \mathrm{M} \Omega$ to $10.81 \mathrm{M} \Omega$. Rising TCR is $-10.49 \times 10^{-3}{ }^{\circ} \mathrm{C}^{-1}$ and falling TCR is $8.00 \times 10^{-3}{ }^{\circ} \mathrm{C}^{-1}$ respectively. For 20 min deposition sample, resistance decreased from $31.15 \mathrm{M} \Omega$ to $8.89 \mathrm{M} \Omega$ as temperature increased from $25^{\circ} \mathrm{C}$ to $100{ }^{\circ} \mathrm{C}$. Resistance increased from $8.80 \mathrm{M} \Omega$ to $28.54 \mathrm{M} \Omega$ during the reverse process (Figure $5 \mathrm{c}$ ). The obtained rising TCR is $-10.02 \times 10^{-3}{ }^{\circ} \mathrm{C}^{-1}$ and falling TCR is $8.88 \times 10^{-3}{ }^{\circ} \mathrm{C}^{-1}$. A similar trend was recorded in the third sample; seed layer deposited for $30 \mathrm{~min}$ with resistance decreasing from $130.19 \mathrm{M} \Omega$ to 0.72 as temperature increased from $25^{\circ} \mathrm{C}$ to $100{ }^{\circ} \mathrm{C}$. The condition of temperature decreased from $100{ }^{\circ} \mathrm{C}$ to $25^{\circ} \mathrm{C}$ and resulted in a resistance rise from $0.61 \mathrm{M} \Omega$ to $123.72 \mathrm{M} \Omega$. Rising and falling TCR are $-11.09 \times 10^{-3}{ }^{\circ} \mathrm{C}^{-1}$ and $10.82 \times 10^{-3}{ }^{\circ} \mathrm{C}^{-1}$ respectively (Figure $5 \mathrm{~d}$ ). The resistance in the $10 \mathrm{~min} \mathrm{ZnO}$ seeds sample is a single-valued function of temperature up to $80^{\circ} \mathrm{C}$, above which there is a sudden reduction in sensitivity. A similar trend is observed in the sensor with 20 min deposition time. However, it exhibits a region within a temperature range of $30-40{ }^{\circ} \mathrm{C}$, in which resistance is multivalued at different temperatures, which makes the device unusable for temperature measurements close to the body temperature. Moreover, an increase in deposition time to $30 \mathrm{~min}$ displayed a linear resistance-temperature function below $40{ }^{\circ} \mathrm{C}$ coupled with high sensitivity which is appropriate for temperature measurements close to the body temperature. In contrast, there is no appreciable change in resistance with temperatures above $60^{\circ} \mathrm{C}$. The average TCR value was highest when the seed layer deposition time was $30 \mathrm{~min}$. However, the linearity of $30 \mathrm{~min}$ deposition sample was weaker than other samples. Even though the $30 \mathrm{~min}$ seeded sample exhibited a downgraded crystallinity quality compared to the 20 min seeded sample, it showed the best TCR. We speculate that the sensing performance does not depend only on crystallinity but the grain size also maximizes the sensing ability. The 30 min seeded sample exhibited the largest grain size, which provides a larger number of boundaries for temperature sensing. This is reasonable to conclude that the crystallinity, as well the grain size is essential to attain sensing capacities. The crystallinity and grain size of $\mathrm{ZnO} / \mathrm{V}_{2} \mathrm{O}_{5}$ composite affected its temperature sensing ability.

\subsection{Electrochemical Sensor}

\subsubsection{Glucose Sensor}

In the electrode preparation, carbon black and PVDF were mixed with the active material respectively to improve the conductivity and stability upon voltage application. $17 \mathrm{mM}$ PBS employed as a working electrolyte has a $\mathrm{pH}$ of 7.4 which lies between the isoelectric points of $\mathrm{ZnO}$ of 9.2 and glucose of 4.2 respectively. This renders $\mathrm{ZnO}$ surface positively charged and glucose negatively charged. Among the families of enzymes associated with glucose metabolism, GOx is employed in our experiment because of its high activity and availability. In addition, Nafion was coated on the GOx layer to reduce the enzyme leakage. The probable mechanism involves an initial interaction of GOx with glucose. Glucose is converted to gluconolactone and finally to gluconic acid with the release of $\mathrm{H}_{2} \mathrm{O}_{2}$. The $\mathrm{H}_{2} \mathrm{O}_{2}$ decomposes 
into an oxygen molecule and protons by generating electrons which are responsible for the current-potential characteristic for glucose sensing [33]. The glucose-sensing phenomenon is well elaborated in the following reactions:

$$
\begin{gathered}
\mathrm{O}_{2} \rightarrow \mathrm{O}_{2 \text { ads }}(\mathrm{ZnO}) \\
\mathrm{O}_{2(\text { ads })}\left(\mathrm{ZnO} / \mathrm{V}_{2} \mathrm{O}_{5}\right)+2 \mathrm{e}^{-}(\mathrm{ZnO}) \rightarrow 2 \mathrm{O}_{(\text {ads })}^{-}\left(\mathrm{O}^{-} / \mathrm{O}^{2-}\right) \\
\text { Glucose }+\mathrm{O}^{-} \stackrel{\text { GOx }}{\rightarrow} \text { Glucono }-\delta-\text { lactone }+2 \mathrm{e}^{-}
\end{gathered}
$$

Initially, the accessible $\mathrm{O}$ in the glucose atmosphere was adsorbed onto the surface of $\mathrm{ZnO} / \mathrm{V}_{2} \mathrm{O}_{5}$ as an oxygen $(\mathrm{O})$ monolayer. The neutral $\mathrm{O}$ was then activated to $\left(\mathrm{O}^{-} / \mathrm{O}^{2-}\right)$. Finally, glucono- $\delta$-lactone is produced from glucose oxidation through a biochemical process catalyzed by GOx. The sensing electrode detects the electron transfer by reading the current. A schematic diagram of the glucose sensor is represented in Scheme S2 in the supplementary materials. The high surface area of $\mathrm{ZnO} / \mathrm{V}_{2} \mathrm{O}_{5}$ provides a good aspect ratio for GOx immobilization and contributes to the high current detection by influencing the electron transfer through structural arrangement [40].

In Figure S6, the CV curves were first plotted for GOx (without $\mathrm{V}_{2} \mathrm{O}_{5}$ and $\mathrm{ZnO} / \mathrm{V}_{2} \mathrm{O}_{5}$ ) within a large potential window $(0-1.5 \mathrm{~V}$ vs. $\mathrm{Ag} / \mathrm{AgCl})$. An observation of a hump clearly shows that $\mathrm{H}_{2} \mathrm{O}_{2}$ oxidation is around $600 \mathrm{mV}$ [41]. The $\mathrm{CV}$ curves were also measured within an applied potential from $-1.0 \mathrm{~V}$ to $1.0 \mathrm{~V}$ with $0.1 \mathrm{mM}$ with glucose as the analyte in $17 \mathrm{mM}$ PBS electrolyte in the presence of $\mathrm{ZnO}$ and $\mathrm{ZnO} / \mathrm{V}_{2} \mathrm{O}_{5}$ electrodes. The $\mathrm{CV}$ curves illustrated in Figure 6a show characteristic cathodic and anodic peaks. Increasing the scan rate resulted in a positive potential shift of the cathodic peak and a negative potential shift of the anodic peak [30]. Interestingly, two cathodic peaks were observed with one considerably below $-100 \mathrm{mV}$ and the other slightly above $600 \mathrm{mV}$. However, a calibrated potential higher than the latter was selected to construct the calibration curve because detection of enzymatic reaction (oxidation of $\mathrm{H}_{2} \mathrm{O}_{2}$ ) takes place at $600 \mathrm{mV}$ at $\mathrm{Pt}$ electrode [33].

To study glucose sensitivity, a calibration curve (both with and without electrodes) was plotted at $+0.8 \mathrm{~V}$ as shown in Figure $6 \mathrm{~b}$ for glucose concentration $(100 \mu \mathrm{M}-10 \mathrm{mM})$ which was observed to exhibit a linear characteristic. $\mathrm{ZnO}$ layer deposition was selected with $10 \mathrm{~min}$ and $30 \mathrm{~min}$ represented in Figure S7. After linear fitting, correlation coefficient $\left(\mathrm{R}^{2}\right)$ is 0.9964 for $\mathrm{ZnO}$ microrods and 0.9941 for composite. The right current was calculated as the recorded current minus the blank signal. Glucose sensitivity, limit of detection (LOD), and limit of quantification (LOQ) were calculated from the equations;

$$
\begin{aligned}
& \text { Sensitivity }=\frac{\mathrm{m}}{\mathrm{A}} \\
& \mathrm{LOD}=\frac{(3 \times \mathrm{SD})}{\mathrm{m}} \\
& \mathrm{LOQ}=\frac{(10 \times \mathrm{SD})}{\mathrm{m}}
\end{aligned}
$$

where, A-active surface area of PET working electrode, $\mathrm{m}$-slope of the calibration curve, and SD—standard deviation at the calibrated potential (0.79). 

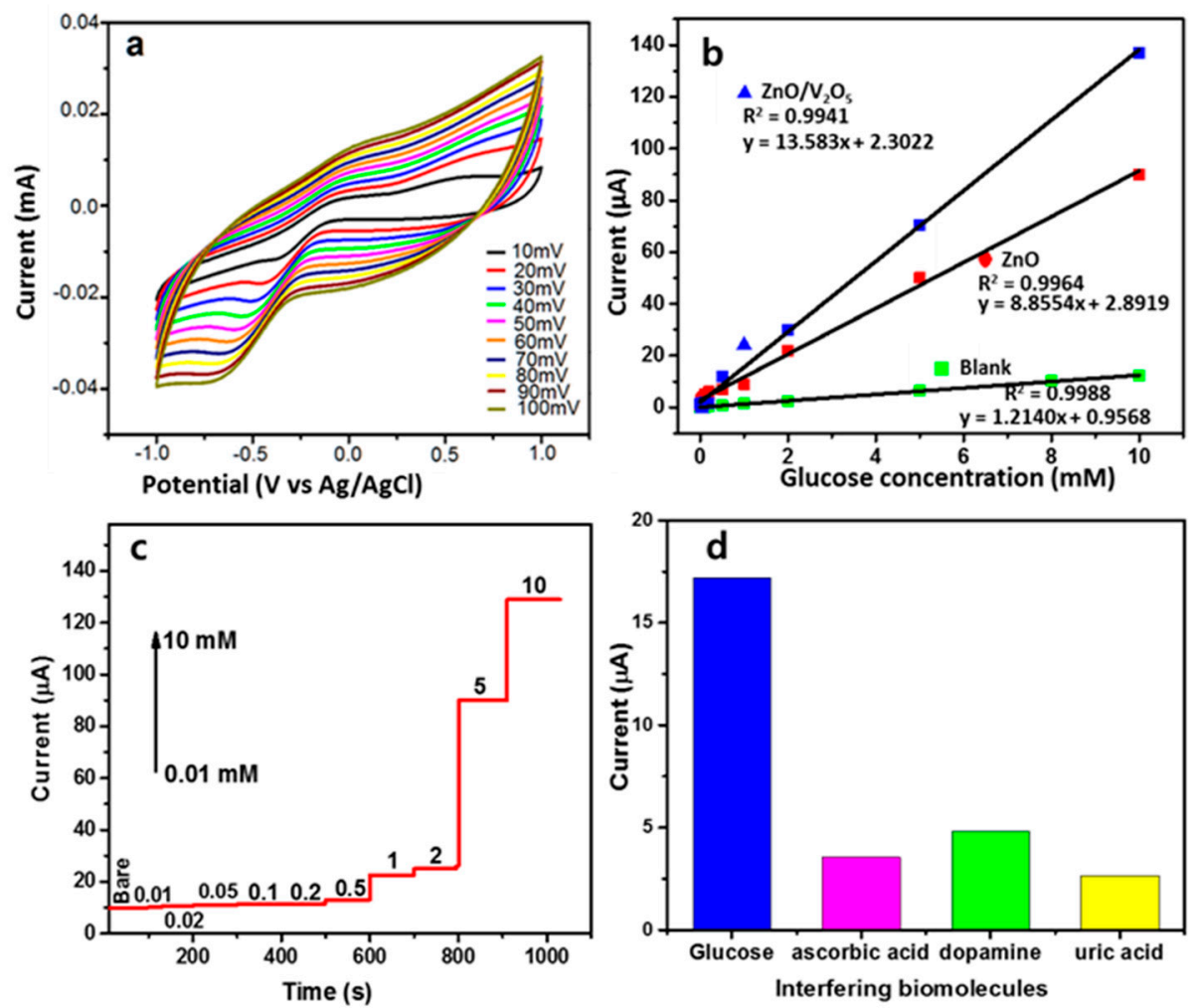

Figure 6. (a) Cyclic voltammetry curve of $\mathrm{ZnO} / \mathrm{V}_{2} \mathrm{O}_{5}$ electrode at different scan rate applied in glucose sensing, (b) calibration plot of blank, $\mathrm{ZnO}$ and $\mathrm{ZnO} / \mathrm{V}_{2} \mathrm{O}_{5}$ glucose sensors at $+0.8 \mathrm{~V}$ with a straight line representing the linear fit for $\mathrm{ZnO}$ seed layer deposited on PET for $20 \mathrm{~min}$, (c) current-time response monitoring according to increasing glucose concentration towards $\mathrm{ZnO} / \mathrm{V}_{2} \mathrm{O}_{5}$ electrode, and (d) bar diagram representation of the interference effect at $+1.0 \mathrm{~V}$.

The active surface area of PET fiber was calculated; $A=2 \pi R L$, where $R$ stands for radius and $L$ stands for the active length of PET fiber, $A=2 \times \pi \times 0.015 \mathrm{~cm} \times 2 \mathrm{~cm}=$ $0.1885 \mathrm{~cm}^{2}$. Table S1 shows a summary of the sensitivity, limit of detection (LOD), and limit of quantification (LOQ) of both $\mathrm{ZnO}$ and $\mathrm{ZnO} / \mathrm{V}_{2} \mathrm{O}_{5}$ electrodes at different deposition times. We observe that the seed layer deposited for 20 min demonstrates optimum glucose sensing with highest sensitivity and lowest LOD. High sensitivity $\left(72.06 \mu \mathrm{AmM}^{-1} \mathrm{~cm}^{-2}\right)$, LOD $(0.174 \mathrm{mM})$, and LOQ $(0.582 \mathrm{mM})$ were recorded for the proposed $\mathrm{ZnO} / \mathrm{V}_{2} \mathrm{O}_{5}$ based glucose sensor on 20 min seed layer PET fiber. $\mathrm{ZnO}$ on the other hand exhibited lower performance of sensitivity $\left(46.98 \mu \mathrm{AmM}^{-1} \mathrm{~cm}^{-2}\right)$, LOD $(0.268 \mathrm{mM})$, and LOQ $(0.892 \mathrm{mM})$ at equivalent measuring conditions all in a linear dynamic range (LDR) of $10 \mu \mathrm{M}-10 \mathrm{mM}$. Figure $6 \mathrm{c}$ shows a continuous increase in current with increase in glucose concentration. The glucose sensing performance of $\mathrm{ZnO} / \mathrm{V}_{2} \mathrm{O}_{5}$ is compared with several previously published works as represented in Table 1 . It is noticeable that the I-V design is reliable and offers remarkable glucose sensitivity with low LOD. This renders the proposed electrode a potential glucose sensor that can be integrated in next generation sensors.

Table 1. Comparison of glucose sensing ability of $\mathrm{ZnO} / \mathrm{V}_{2} \mathrm{O}_{5}$ electrode with previously published for sensor application.

\begin{tabular}{|c|c|c|c|c|c|}
\hline Electrode & Method of Detection & $\operatorname{LOD}^{1}(\mu \mathrm{M})$ & $\operatorname{LDR}^{2}(\mu \mathrm{M})$ & $\begin{array}{c}\text { Sensitivity } \\
\left(\mu \mathrm{AmM}^{-1} \mathrm{~cm}^{-2}\right)\end{array}$ & Reference \\
\hline $\mathrm{MnO}_{2} / \mathrm{MWCNT}$ & Amperometry & - & $10-28,000$ & 33.19 & [42] \\
\hline $\mathrm{V}_{2} \mathrm{O}_{5}$ nanoenzymes & Chronoamperometry & 10 & $10-2000$ & - & [43] \\
\hline $\mathrm{ZnONR}$ & Amperometry & 0.22 & - & 0.0109 & [23] \\
\hline $\mathrm{ZnO} / \mathrm{V}_{2} \mathrm{O}_{5} \mathrm{NR}$ & $\mathrm{I}-\mathrm{V}$ & 125,250 & $1-1000$ & 1.27 & [33] \\
\hline $\mathrm{ZnO} / \mathrm{V}_{2} \mathrm{O}_{5}$ on PET & Amperometry & 174 & $10-10,000$ & 72.06 & This work \\
\hline
\end{tabular}

\footnotetext{
${ }^{1}$ Limit of Detection. ${ }^{2}$ Linear Dynamic Range.
} 
To study mechanical stability and strength of $\mathrm{ZnO} / \mathrm{V}_{2} \mathrm{O}_{5}$, the PET fiber array was bent repetitively. The curvature of bend was $0.048 \mathrm{~mm}^{-1}$ with an applied strain of bending $36.7 \%$. After bending, the current was measured at different glucose concentrations and the glucose sensitivity analysis at calibrated potential, $+1.0 \mathrm{~V}$ was represented in Figure S9a-c. The $\mathrm{ZnO} / \mathrm{V}_{2} \mathrm{O}_{5}$ based electrochemical glucose sensor exhibited $12.2430 \mu \mathrm{AmM}^{-1} \mathrm{~cm}^{-2}$ $\left(\mathrm{R}^{2}=0.9628\right), 11.2546 \mu \mathrm{AmM}^{-1} \mathrm{~cm}^{-2}\left(\mathrm{R}^{2}=0.9367\right)$ and $\left(5.9576 \mu \mathrm{AmM}^{-1} \mathrm{~cm}^{-2} \mathrm{R}^{2}=0.9533\right)$ after 50 cycles, 100 cycles and 200 cycles of bending. This represents $16.99 \%, 15.62 \%$, and $8.27 \%$ of the initial sensitivity. Figure S9d depicts a summary of mechanical stability of the glucose sensor. The sensitivity loss may be due to bending of fiber substrate which resulted in cracks on $\mathrm{ZnO} / \mathrm{V}_{2} \mathrm{O}_{5}$ electrode rendering the linearity of glucose sensitivity and conductivity is aggravated [44].

Interference examination is one of the most important tools in analytical science to differentiate biomolecules showing similar physiological characteristics. Dopamine, ascorbic, and uric acid were employed as interfering constituents towards $\mathrm{ZnO} / \mathrm{V}_{2} \mathrm{O}_{5}$ glucose sensors in this study [45]. The I-V characteristic was recorded upon addition of $(1 \mathrm{~mL}, 5 \mathrm{mM})$ each of dopamine, ascorbic acid, and uric acid in $(15 \mathrm{~mL}, 17 \mathrm{mM})$ PBS solution. Table 2 shows a summary of the current response towards the addition of $(0.5 \mathrm{~mL}, 100 \mu \mathrm{M})$ each of the interfering molecules into $(10 \mathrm{~mL}, 17 \mathrm{mM})$ of PBS solution. The interference effects of these biomolecules using glucose as reference are calculated at calibrated potential $(+1.0 \mathrm{~V})$ and summarized in Figure 6d. It is observed dopamine, ascorbic and uric acid showed minimal interference towards $\mathrm{ZnO} / \mathrm{V}_{2} \mathrm{O}_{5}$ which renders the proposed sensor selective to glucose detection with high sensitivity.

Table 2. Interference effect of similar biomolecules towards $\mathrm{ZnO} / \mathrm{V}_{2} \mathrm{O}_{5}$ sensing electrode.

\begin{tabular}{|c|c|c|c|c|c|}
\hline \multirow{2}{*}{ IBM } & \multicolumn{4}{|c|}{$\mathrm{CR}, \mathrm{uA}$} & \multirow{2}{*}{ IE (\%) } \\
\hline & R1 & R2 & R3 & Avg & \\
\hline G & 20.32 & 18.68 & 12.64 & 17.21 & 100 \\
\hline AA & 3.20 & 4.31 & 3.11 & 3.54 & 20.6 \\
\hline $\mathrm{D}$ & 5.61 & 4.64 & 4.16 & 4.80 & 28.9 \\
\hline UA & 1.93 & 3.12 & 2.86 & 2.64 & 15.3 \\
\hline
\end{tabular}

$(0.5 \mathrm{~mL}, 100 \mu \mathrm{M}) \mathrm{IBM}$ - interfering molecules, IE-interfering effect, CR-current recorded, G-glucose, AAascorbic acid, D-dopamine, UA-uric acid, R-reading, Avg-average.

\subsection{2. $\mathrm{pH}$ Sensor}

In addition to the glucose sensing property, $\mathrm{ZnO} / \mathrm{V}_{2} \mathrm{O}_{5}$ showed sensitivity toward $\mathrm{pH}$. As previously mentioned, large surface area-to-volume ratio, makes $\mathrm{ZnO}$ an excellent material for $\mathrm{pH}$ sensing. Rather than $17 \mathrm{mM} \mathrm{PBS}, \mathrm{NaOH}$ and $\mathrm{HCl}$ solutions containing different concentrations were used for the electrolyte. Cyclic voltammetry curves at different scan rates of the prepared electrode in $\mathrm{pH} 4$ solution are depicted in Figure 7a. High anodic peak and cathodic peak currents are apparent which are an indication of a promising $\mathrm{pH}$ sensing characteristic. This type of metal oxide is a typical amphoteric oxide material that reacts with both acidic solution and basic solution. [46] Zn shows electropositive features in acidic medium and electronegative features in alkaline medium. Figure $7 \mathrm{~b}$ explains the potential variation with changes in $\mathrm{pH}$. Performing a linear fit produced the slope which is an indication of the $\mathrm{pH}$ sensitivity. A high sensitivity of $41.95 \mathrm{mV} / \mathrm{pH}\left(\mathrm{R}^{2}=0.9934\right)$ was recorded for $\mathrm{ZnO} / \mathrm{V}_{2} \mathrm{O}_{5}$ composite and $42.26 \mathrm{mV} / \mathrm{pH}$ of sensitivity $\left(\mathrm{R}^{2}=0.9922\right)$ for $\mathrm{ZnO}$ which represent $71.1 \%$ and $71.6 \%$ of the ideal Nernstian limit $(59.14 \mathrm{mV} / \mathrm{pH})$. From the Nernst equation, the number of electrons transferred during the redox reaction of $\mathrm{ZnO}$ and $\mathrm{ZnO} / \mathrm{V}_{2} \mathrm{O}_{5}$ is responsible for the lower response compared to only one electron for monovalent ions $\left(\mathrm{H}^{+}\right)$. The potential-time response in different $\mathrm{pH}$ solutions towards $\mathrm{ZnO} / \mathrm{V}_{2} \mathrm{O}_{5}$ and $\mathrm{ZnO}$ are indicated in Figure $7 \mathrm{c}$ and Figure S10a respectively. It can be deduced that $\mathrm{ZnO}$ and $\mathrm{ZnO} / \mathrm{V}_{2} \mathrm{O}_{5}$ composite showed a high potential in an acidic environment and low potential in a basic environment. 

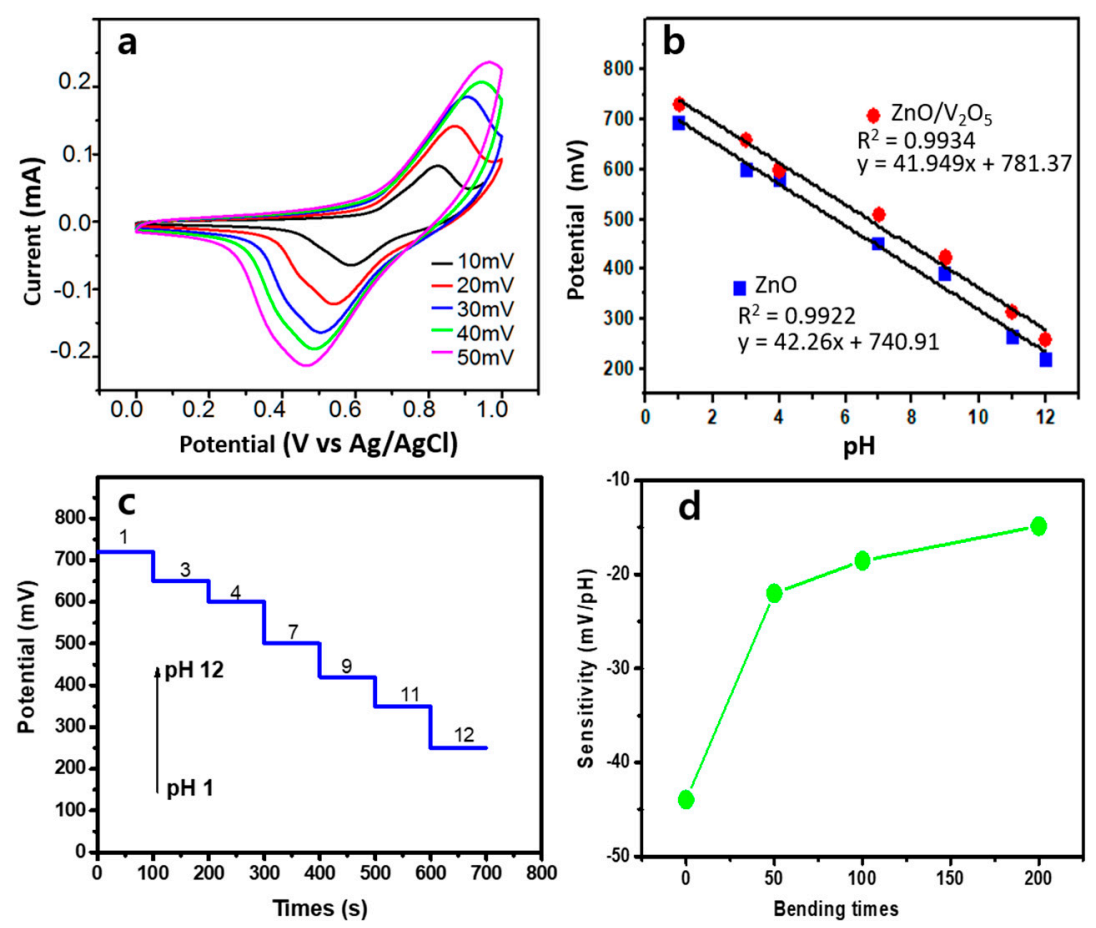

Figure 7. (a) Cyclic voltammetry curve of $\mathrm{ZnO} / \mathrm{V}_{2} \mathrm{O}_{5}$ electrode at different scan rates in $\mathrm{NaOH} / \mathrm{HCl}$ mixture of $\mathrm{pH} 4$, (b) calibration plot for $\mathrm{ZnO}$ and $\mathrm{ZnO} / \mathrm{V}_{2} \mathrm{O}_{5} \mathrm{pH}$ sensors with a straight line representing the linear fit, (c) potential-time response obtained on increasing the $\mathrm{pH}$ of $\mathrm{NaOH} / \mathrm{HCl}$ electrolyte at $\mathrm{ZnO} / \mathrm{V}_{2} \mathrm{O}_{5}$ electrode, and (d) calculated sensitivity after various bending cycles to validate the mechanical stability of $\mathrm{ZnO} / \mathrm{V}_{2} \mathrm{O}_{5} \mathrm{pH}$ sensors.

Potential change upon repetitive bending was plotted in Figure S10b,d for different bending cycles. Potential value and $\mathrm{pH}$ sensitivity slightly decreased after repetitive bending test. The curvature of bend was maintained at $0.048 \mathrm{~mm}^{-1}$ with an applied strain of bending $36.7 \%$ same as in the bending test on the glucose sensor. The exhibited $\mathrm{pH}$ sensitivity is $21.99 \mathrm{mV} / \mathrm{pH}\left(\mathrm{R}^{2}=0.8692\right), 18.54 \mathrm{mV} / \mathrm{pH}\left(\mathrm{R}^{2}=0.9481\right)$ and $14.85 \mathrm{mV} / \mathrm{pH}$ $\left(R^{2}\right.$ is 0.9143$)$ after 50 cycles of bending, 100 cycles bending and 200 cycles of bending respectively. As shown in Figure $7 \mathrm{~d}$, there is a drastic reduction in the sensitivity after 50 cycles of bending with slight reduction for subsequent bends. This observation, we attribute to a sudden loss of stability due to the stress induced in the PET fiber. Overall performance of the $\mathrm{ZnO}$ microrods coated PET fiber exhibits reasonable $\mathrm{pH}$ sensitivity performances of $25 \%$ of the Nernst limit after 200 cycles bending conditions.

\section{Conclusions}

This work explains fabrication of a highly flexible trifunctional sensor which features temperature, glucose, and $\mathrm{pH}$ detection on a cylindrical PET fiber. Uniform and even surface deposition of $\mathrm{ZnO}$ layer was obtained by using a rotating device inside the sputter chamber. The main component of the sensitive layer, $\mathrm{ZnO} / \mathrm{V}_{2} \mathrm{O}_{5}$ was synthesized using hydrothermal reaction and deposited on the $\mathrm{ZnO}$ seed layer. The pristine $\mathrm{ZnO} / \mathrm{V}_{2} \mathrm{O}_{5}$ hexagonal-like rods were characterized using XRD, XPS, FESEM, and CV. Compared to single $\mathrm{ZnO}$ microrods, the $\mathrm{ZnO} / \mathrm{V}_{2} \mathrm{O}_{5}$ electrode exhibits better electrical activity towards temperature and electrochemical sensors. It recorded better reversibility for both rising and falling conditions with maximum TCR of $0.0111^{\circ} \mathrm{C}^{-1}$ at $30 \mathrm{~min} \mathrm{ZnO}$ layer deposition. An outstanding glucose sensing performance was achieved with $\mathrm{ZnO} / \mathrm{V}_{2} \mathrm{O}_{5}$. It displayed a linear dependence $(R=0.9941)$ in a glucose concentration between $(10 \mu \mathrm{M}-10 \mathrm{mM})$ with a sensitivity of $72.06 \mu \mathrm{AmM}^{-1} \mathrm{~cm}^{-2}$ and a limit of detection at $174 \mu \mathrm{M}$ at optimum $20 \mathrm{~min}$ deposition time. $\mathrm{ZnO} / \mathrm{V}_{2} \mathrm{O}_{5}$ glucose sensor could retain only $8.3 \%$ of sensing ability after 200 bending cycles. Ascorbic acid, dopamine, and uric acid displayed negligible inter- 
ference making $\mathrm{ZnO} / \mathrm{V}_{2} \mathrm{O}_{5}$ selective to glucose molecules. Also, the fabricated electrode exhibited $\mathrm{pH}$ sensitivity of $42.26 \mathrm{mV} / \mathrm{pH}\left(\mathrm{R}^{2}=0.9922\right)$ which is about $72 \%$ of the Nernstian response. After repetitive bending, the device showed good mechanical stability which appeals to its potential to be developed as a multifunctional (temperature, glucose, and $\mathrm{pH}$ ) sensor. The sensor would be installed outside the human body. It could be woven into comfortable, form-fitting, or stretchy fabrics to remotely track temperature, glucose, and pH signals.

Supplementary Materials: The following are available online at https: / www.mdpi.com/article / 10.3390/s21072559/s1, Figure S1: photographic image of (a) sputtering jig for rotating PET fiber (b) PET fiber and $\mathrm{ZnO} / \mathrm{V}_{2} \mathrm{O}_{5}$ coated PET fiber, Figure S2: SEM image of PET fiber, Figure S3: cross-sectional SEM image of $\mathrm{ZnO} / \mathrm{V}_{2} \mathrm{O}_{5}$ composite on $\mathrm{ZnO}$ seeds. Figure S4: SEM-EDX pattern of $\mathrm{ZnO} / \mathrm{V}_{2} \mathrm{O}_{5}$ showing the elemental composition. Figure S5: XRD patterns of $\mathrm{ZnO}$ microrods deposited with seed layer deposition time of (a) $10 \mathrm{~min} \mathrm{(b)} 20 \mathrm{~min}$, and (c) $30 \mathrm{~min}$, Scheme S2: schematic representation of the electrochemical sensor testing. $\mathrm{RE}, \mathrm{CE}$, and WE represent reference electrode, counter electrode, and working electrode respectively, Figure S6: CV profiles for GOx in the absence of $\mathrm{ZnO}$ or $\mathrm{ZnO} / \mathrm{V}_{2} \mathrm{O}_{5}$ (blank solution) at different scan rates, Figure S7: calibration plot of $\mathrm{ZnO}$ and $\mathrm{ZnO} / \mathrm{V}_{2} \mathrm{O}_{5}$ glucose sensors at $+0.8 \mathrm{~V}$ with a straight line representing the linear fit for (a) $10 \mathrm{~min}$ and (b) $30 \mathrm{~min} \mathrm{ZnO}$ seed layer deposition times on PET substrates, Figure S8: current-time response monitoring according to increasing glucose concentration towards $\mathrm{ZnO}$ electrode, Figure S9: calibration plot for $\mathrm{ZnO} / \mathrm{V}_{2} \mathrm{O}_{5}$ glucose sensing at $+1.0 \mathrm{~V}$ with a straight line representing the linear fit for ZnO seed layer deposited on PET for 20min after (a) 50 cycles (b) 100 cycles (c) 200 cycles (d) variation of calculated sensitivity after various bending cycles, Figure S10: (a) potential-time response obtained on increasing the $\mathrm{pH}$ of $\mathrm{NaOH} / \mathrm{HCl}$ electrolyte for $\mathrm{ZnO}$ electrode. Calibration plot for $\mathrm{ZnO} / \mathrm{V}_{2} \mathrm{O}_{5} \mathrm{pH}$ sensors with a straight line representing the linear fit after (a) 50 cycles (b) 100 cycles (c) 200 cycles of repetitive bending, Table S1 sensitivity, limit of detection (LOD), and limit of quantification (LOQ) of $\mathrm{ZnO}$ and $\mathrm{ZnO} / \mathrm{V}_{2} \mathrm{O}_{5}$ glucose sensor on $\mathrm{ZnO}$ seed layer at different deposition times.

Author Contributions: Conceptualization, A.B.A.; methodology, A.B.A.; validation, A.B.A. and J.I.H.; formal analysis, A.B.A.; investigation, A.B.A. and J.I.H.; data curation, A.B.A.; project administration, J.I.H.; writing—original draft preparation, A.B.A.; writing—review and editing, J.I.H.; supervision, J.I.H.; funding acquisition, J.I.H. All authors have read and agreed to the published version of the manuscript.

Funding: This research was supported by the Technology Innovation Program (20004981, Development of Integrated Smart Seat and Skin Material based on Electronic Fabric) funded by the Ministry of Trade, Industry \& Energy (MOTIE, Korea).

Institutional Review Board Statement: Not applicable.

Informed Consent Statement: Not applicable.

Data Availability Statement: The data presented in this work are available on request from the corresponding author.

Conflicts of Interest: The authors declare that they have no known competing financial interests or personal relationships that could have appeared to influence the work reported in this paper.

\section{References}

1. Khan, Y.; Thielens, A.; Muin, S.; Ting, J.; Baumbauer, C.; Arias, A.C. A New Frontier of Printed Electronics: Flexible Hybrid Electronics. Adv. Mater. 2020, 32, e1905279. [CrossRef]

2. Poh, M.Z.; Swenson, N.C.; Picard, R.W. A wearable sensor for unobtrusive, long-term assessment of electrodermal activity. IEEE Trans. Biomed. Eng. 2010, 57, 1243-1252. [CrossRef] [PubMed]

3. Gao, W.; Emaminejad, S.; Nyein, H.Y.Y.; Challa, S.; Chen, K.; Peck, A.; Fahad, H.M.; Ota, H.; Shiraki, H.; Kiriya, D.; et al. Fully integrated wearable sensor arrays for multiplexed in situ perspiration analysis. Nature 2016, 529, 509-514. [CrossRef] [PubMed]

4. Li, Y.Q.; Zhu, W.B.; Yu, X.G.; Huang, P.; Fu, S.Y.; Hu, N.; Liao, K. Multifunctional Wearable Device Based on Flexible and Conductive Carbon Sponge/Polydimethylsiloxane Composite. ACS Appl. Mater. Interfaces 2016, 8, 33189-33196. [CrossRef] [PubMed] 
5. Ryu, S.; Lee, P.; Chou, J.B.; Xu, R.; Zhao, R.; Hart, A.J.; Kim, S.G. Extremely Elastic Wearable Carbon Nanotube Fiber Strain Sensor for Monitoring of Human Motion. ACS Nano 2015, 9, 5929-5936. [CrossRef] [PubMed]

6. Wang, Y.; Zhang, L.; Zhang, Z.; Sun, P.; Chen, H. High-Sensitivity Wearable and Flexible Humidity Sensor Based on Graphene Oxide/Non-Woven Fabric for Respiration Monitoring. Langmuir 2020, 36, 9443-9448. [CrossRef] [PubMed]

7. Yu, Y.; Peng, S.; Blanloeuil, P.; Wu, S.; Wang, C.H. Wearable Temperature Sensors with Enhanced Sensitivity by Engineering Microcrack Morphology in PEDOT:PSS-PDMS Sensors. ACS Appl. Mater. Interfaces 2020, 12, 36578-36588. [CrossRef] [PubMed]

8. He, J.; Zhang, Y.; Zhou, R.; Meng, L.; Chen, T.; Mai, W.; Pan, C. Recent advances of wearable and flexible piezoresistivity pressure sensor devices and its future prospects. J. Mater. 2020, 6, 86-101. [CrossRef]

9. Parlak, O.; Curto, V.F.; Ojeda, E.; Basabe-Desmonts, L.; Benito-Lopez, F.; Salleo, A. Wearable biosensors and sample handling strategies. In Wearable Bioelectronics; Elsevier: Amsterdam, The Netherlands, 2019; pp. 65-88. ISBN 9780081024072.

10. Tan, C.; Dong, Z.; Li, Y.; Zhao, H.; Huang, X.; Zhou, Z.; Jiang, J.W.; Long, Y.Z.; Jiang, P.; Zhang, T.Y.; et al. A high performance wearable strain sensor with advanced thermal management for motion monitoring. Nat. Commun. 2020, 11, 1-10. [CrossRef]

11. Manjakkal, L.; Dervin, S.; Dahiya, R. Flexible potentiometric pH sensors for wearable systems. RSC Adv. 2020, 10, 8594-8617. [CrossRef]

12. Huang, Q.; Zhu, Y. Printing Conductive Nanomaterials for Flexible and Stretchable Electronics: A Review of Materials, Processes, and Applications. Adv. Mater. Technol. 2019, 4, 1800546. [CrossRef]

13. Yuen, J.D.; Baingane, A.; Hasan, Q.; Shriver-Lake, L.C.; Walper, S.A.; Zabetakis, D.; Breger, J.C.; Stenger, D.A.; Slaughter, G. A Fully-Flexible Solution-Processed Autonomous Glucose Indicator. Sci. Rep. 2019, 9, 1-9. [CrossRef] [PubMed]

14. Xu, J.; Su, W.; Li, Z.; Liu, W.; Liu, S.; Ding, X. A modularized and flexible sensor based on MWCNT/PDMS composite film for on-site electrochemical analysis. J. Electroanal. Chem. 2017, 806, 68-74. [CrossRef]

15. Bi, C.; Chen, B.; Wei, H.; DeLuca, S.; Huang, J. Efficient Flexible Solar Cell based on Composition-Tailored Hybrid Perovskite. Adv. Mater. 2017, 29. [CrossRef] [PubMed]

16. Hilal, A.M.; Han, B.J.I. Development of a Highly Flexible and Durable Fiber-Shaped Temperature Sensor based on Graphene/Ni Double-Decked Layer for Wearable Devices. IEEE Sens. J. 2020. [CrossRef]

17. Eom, T.H.; Han, J.I. The effect of the nickel and chromium concentration ratio on the temperature coefficient of the resistance of a $\mathrm{Ni}-\mathrm{Cr}$ thin film-based temperature sensor. Sens. Actuators A Phys. 2017, 260, 198-205. [CrossRef]

18. Kaidarova, A.; Khan, M.A.; Marengo, M.; Swanepoel, L.; Przybysz, A.; Muller, C.; Fahlman, A.; Buttner, U.; Geraldi, N.R.; Wilson, R.P.; et al. Wearable multifunctional printed graphene sensors. npj Flex. Electron. 2019, 3, 1-10. [CrossRef]

19. Yao, S.; Zhu, Y. Wearable multifunctional sensors using printed stretchable conductors made of silver nanowires. Nanoscale 2014, 6, 2345-2352. [CrossRef]

20. Girija, K.G.; Somasundaram, K.; Topkar, A.; Vatsa, R.K. Highly selective $\mathrm{H}_{2} \mathrm{~S}$ gas sensor based on Cu-doped ZnO nanocrystalline films deposited by RF magnetron sputtering of powder target. J. Alloys Compd. 2016, 684, 15-20. [CrossRef]

21. Liao, X.; Liao, Q.; Zhang, Z.; Yan, X.; Liang, Q.; Wang, Q.; Li, M.; Zhang, Y. A Highly Stretchable ZnO@Fiber-Based Multifunctional Nanosensor for Strain/Temperature/UV Detection. Adv. Funct. Mater. 2016, 26, 3074-3081. [CrossRef]

22. Hasan, S.A.; Gibson, D.; Song, S.; Wu, Q.; Ng, W.P.; McHale, G.; Dean, J.; Fu, Y.Q. ZnO thin film based flexible temperature sensor. In Proceedings of the IEEE Sensors, Glasgow, UK, 29 October-1 November 2017; pp. 1-3.

23. Marie, M.; Mandal, S.; Manasreh, O. An Electrochemical Glucose Sensor Based on Zinc Oxide Nanorods. Sensors 2015, 15, 18714-18723. [CrossRef] [PubMed]

24. Ahmad Bhat, B.; Khan, G.R.; Asokan, K. Role of substrate effects on the morphological, structural, electrical and thermoelectrical properties of V2O5 thin films. RSC Adv. 2015, 5, 52602-52611. [CrossRef]

25. Pan, G.X.; Xia, X.H.; Cao, F.; Chen, J.; Zhang, Y.J. Carbon cloth supported vanadium pentaoxide nanoflake arrays as highperformance cathodes for lithium ion batteries. Electrochim. Acta 2014, 149, 349-354. [CrossRef]

26. Liu, H.; Gao, Y.; Zhou, J.; Liu, X.; Chen, Z.; Cao, C.; Luo, H.; Kanehira, M. Growth of oriented vanadium pentaoxide nanostructures on transparent conducting substrates and their applications in photocatalysis. J. Solid State Chem. 2014, 214, 79-85. [CrossRef]

27. Kolodziejczak-Radzimska, A.; Jesionowski, T. Zinc oxide-from synthesis to application: A review. Materials 2014, 7, 2833-2881. [CrossRef] [PubMed]

28. Kim, H.; Pak, Y.; Jeong, Y.; Kim, W.; Kim, J.; Jung, G.Y. Amorphous Pd-assisted $\mathrm{H}_{2}$ detection of ZnO nanorod gas sensor with enhanced sensitivity and stability. Sens. Actuators B Chem. 2018, 262, 460-468. [CrossRef]

29. Jin, W.; Yan, S.; An, L.; Chen, W.; Yang, S.; Zhao, C.; Dai, Y. Enhancement of ethanol gas sensing response based on ordered V2O5 nanowire microyarns. Sens. Actuators B Chem. 2015, 206, 284-290. [CrossRef]

30. Vijayakumar, Y.; Mani, G.K.; Ponnusamy, D.; Shankar, P.; Kulandaisamy, A.J.; Tsuchiya, K.; Rayappan, J.B.B.; Ramana Reddy, M.V. V2O5 nanofibers: Potential contestant for high performance xylene sensor. J. Alloys Compd. 2018, 731, 805-812. [CrossRef]

31. Kesim, Y.E.; Battal, E.; Tanrikulu, M.Y.; Okyay, A.K. An all-ZnO microbolometer for infrared imaging. Infrared Phys. Technol. 2014, 67, 245-249. [CrossRef]

32. Xue, F.; Zhang, L.; Tang, W.; Zhang, C.; Du, W.; Wang, Z.L. Piezotronic effect on ZnO nanowire film based temperature sensor. ACS Appl. Mater. Interfaces 2014, 6, 5955-5961. [CrossRef]

33. Rahman, M.M.; Hussain, M.M.; Asiri, A.M. D-Glucose sensor based on $\mathrm{ZnO} / \mathrm{V}_{2} \mathrm{O}_{5} \mathrm{NRs}$ by an enzyme-free electrochemical approach. RSC Adv. 2019. [CrossRef] 
34. Eom, T.H.; Han, J.I. Resistive behavior of Ni thin film on a cylindrical PET monofilament with temperature for wearable computing devices. Sens. Actuators A Phys. 2017, 259, 96-104. [CrossRef]

35. Anusha, J.R.; Kim, H.J.; Fleming, A.T.; Das, S.J.; Yu, K.H.; Kim, B.C.; Raj, C.J. Simple fabrication of ZnO/Pt/chitosan electrode for enzymatic glucose biosensor. Sens. Actuators B Chem. 2014, 202, 827-833. [CrossRef]

36. Zhang, Q.G.; Zhang, X.; Cao, B.Y.; Fujii, M.; Takahashi, K.; Ikuta, T. Influence of grain boundary scattering on the electrical properties of platinum nanofilms. Appl. Phys. Lett. 2006, 89, 114102. [CrossRef]

37. Wang, Y.T.; Whang, W.T.; Chen, C.H. Hollow $\mathrm{V}_{2} \mathrm{O}_{5}$ nanoassemblies for high-performance room-temperature hydrogen sensors. ACS Appl. Mater. Interfaces 2015, 7, 8480-8487. [CrossRef]

38. Ahmad, R.; Tripathy, N.; Khan, M.Y.; Bhat, K.S.; Ahn, M.S.; Hahn, Y.B. Ammonium ion detection in solution using vertically grown $\mathrm{ZnO}$ nanorod based field-effect transistor. RSC Adv. 2016, 6, 54836-54840. [CrossRef]

39. Wu, Y.; Gao, G.; Yang, H.; Bi, W.; Liang, X.; Zhang, Y.; Zhang, G.; Wu, G. Controlled synthesis of $\mathrm{V}_{2} \mathrm{O}_{5} / \mathrm{MWCNT}$ core/shell hybrid aerogels through a mixed growth and self-assembly methodology for supercapacitors with high capacitance and ultralong cycle life. J. Mater. Chem. A 2015, 3, 15692-15699. [CrossRef]

40. Fang, B.; Zhang, C.; Wang, G.; Wang, M.; Ji, Y. A glucose oxidase immobilization platform for glucose biosensor using ZnO hollow nanospheres. Sens. Actuators B Chem. 2011, 155, 304-310. [CrossRef]

41. Heller, A.; Feldman, B. Electrochemical glucose sensors and their applications in diabetes management. Chem. Rev. 2008, 108, 2482-2505. [CrossRef] [PubMed]

42. Chen, J.; Zhang, W.D.; Ye, J.S. Nonenzymatic electrochemical glucose sensor based on $\mathrm{MnO}_{2} / \mathrm{MWNTs}$ nanocomposite. Electrochem. Commun. 2008, 10, 1268-1271. [CrossRef]

43. Sun, J.; Li, C.; Qi, Y.; Guo, S.; Liang, X. Optimizing colorimetric assay based on $\mathrm{V}_{2} \mathrm{O}_{5}$ nanozymes for sensitive detection of $\mathrm{H}_{2} \mathrm{O}_{2}$ and glucose. Sensors 2016, 16, 584. [CrossRef] [PubMed]

44. Zhang, Y.; Pan, T.; Yang, Z. Flexible polyethylene terephthalate/polyaniline composite paper with bending durability and effective electromagnetic shielding performance. Chem. Eng. J. 2020, 389, 124433. [CrossRef]

45. Hussain, M.M.; Asiri, A.M.; Arshad, M.N.; Rahman, M.M. Fabrication of a Ga ${ }^{3+}$ sensor probe based on methoxybenzylidenebenzenesulfonohydrazide (MBBSH) by an electrochemical approach. New J. Chem. 2018, 42, 1169-1180. [CrossRef]

46. Mani, G.K.; Morohoshi, M.; Yasoda, Y.; Yokoyama, S.; Kimura, H.; Tsuchiya, K. ZnO-Based Microfluidic pH Sensor: A Versatile Approach for Quick Recognition of Circulating Tumor Cells in Blood. ACS Appl. Mater. Interfaces 2017, 9, 5193-5203. [CrossRef] [PubMed] 